\title{
Decorative concrete on white cement: resource provision, technology, properties and cost- effectiveness
}

\author{
Vasily Vorobchuk ${ }^{1}$, Maria Matveeva ${ }^{2}$, and Artem Peshkov, ${ }^{3, *}$ \\ ${ }^{1}$ East-Siberian Institute of the Ministry of Internal Affairs of the Russian Federation, 664074, Irkutsk, \\ Lermontova str., 110, Russia \\ ${ }^{2}$ Irkutsk National Research Technical University, 664074, Irkutsk, Lermontova str., 83, Russia \\ ${ }^{3}$ PCC Russkiye Berega LLC, Profsoyuznaya str., 71, Moscow, Russia
}

\begin{abstract}
Decorative concrete refers to a special kind of concrete. Products made of decorative concrete must meet, in addition to the increased requirements for appearance, certain architectural expressiveness and also certain indicators for strength, durability, and environmental friendliness. In addition, one should strive to reduce the cost of both decorative concrete and products made of such concrete. The analysis is carried out, experimental researches of qualitative indicators of industrial man-caused wastes are also studied: carbide lime, fluoride, sludge-lignin, their material and chemical composition. The possibility of using the analyzed industrial wastes as raw materials for production of white and color cements is established. The physicomechanical properties of the obtained cements and decorative concretes on their basis are studied, the economic efficiency of the proposed technology is determined.
\end{abstract}

\section{Introduction}

In recent years, decorative concretes are increasingly used in construction for the architectural expressiveness of buildings and structures. Using the plastic properties of decorative concrete, they are widely used for molding products of relief surfaces, sculptures, facing slabs, making floors, bas-reliefs, paving slabs, i.e. such concrete can be configured in a variety of configurations. Expansion of the range of products from decorative concrete is associated with the implementation of the State Program of the Russian Federation to create an urban comfortable environment

World practice of construction shows that the field of application of white and colored cements on its basis is as extensive as the usual (gray) and some special types of Portland cement have. White cements are used in the form of facing slabs that perfectly imitate natural stone, plaster, concrete coatings, in the manufacture of floors, steps, sculptures, etc. The lined products have an aesthetic appearance, sufficiently high strength, and durability for longterm operation. The Standard GOST 965 (White Portland cement, technical specifications) [1] regulates the compressive strength of cement stone being not less than 39.2 (grade 400)

* Corresponding author: info@stroyberega.com 
and 49.0 (grade 500). In this case, the coefficient of whiteness of light reflection in $\%$ of the absolute scale should be not less than $80 \%$ (first grade), 75\% (second grade), and 70\% (third grade). Naturally, the production of such cement requires a raw material base, containing a low iron content, and the absence of oxides of manganese, chromium. In other words, the output of white Portland cement is based on the use of pure calcite and kaolin clays, so that the total $\mathrm{Fe} 2 \mathrm{O} 3$ content in white cement does not exceed $0.8 \%$ (1\%) [2].

Most of the research on the production of white Portland cement was carried out, and the technology was worked out in obtaining the most white cement at the Shchurovsky factory. In the USSR, the production of white Portland cement was organized in the Tauz factory in 1936. It was interrupted during the Great Patriotic War and was resumed in 1947. In 1953, the production of white Portland cement was organized in a special workshop at the Shchurovsky factory, starting from the commercial production of colored cements in 1960. Beginning in 1936, these cements were used in the most important buildings in the form of mortar and concrete in the manufacture of facing slabs, floors, and steps of sculptures.

To increase color cements of light color by the joint grinding of clinker and pigment, it is necessary that the crushed clinker has a brightness factor of at least $75-80 \%$; for darker cements, it should be not lower than $60-70 \%$. In this case, pigments should be of high alkalinity. There is not so much raw material in the world that is suitable for the production of such cement. The technology of making white cement is more complicated and more expensive; therefore, as a rule, it costs twice as much as the usual gray Portland cement. Taking into account the requirements for white cement and the fact that the existing cement plant is located in the European part of Russia, the white cement for Eastern Siberia and the Baikal area is expensive and scarce, which affects the cost of finishing works and the production of decorative concrete products.

According to the Eurocement Group holding, out of 180 thousand tons of white cement consumed in Russia in 10 months of 2015, 70 thousand tons account for deliveries from Turkey, as well as for own production (60 thousand tons), for supplies from Egypt (30 thousand tons), and from Denmark (15 thousand tons). The remaining 5 thousand tons are the imports from different countries.

From the above, it should be concluded that there is a strong need to search for raw materials, as well as to develop a new cost-effective, energy-saving technology for the production of white cement and products with its use, taking into account the requirements of aesthetics, strength, durability, environmental friendliness, and economic efficiency

\section{Materials and methods}

The object of the study is the man-caused waste from chemical enterprises and the Baikal Pulp and Paper Mill (BPPM).

The aim of the work is to prove the possibility of obtaining white cement on the basis of mixing man-caused waste with subsequent heat treatment and grinding.

In the process of work, experimental studies of the qualitative indices of industrial mancaused wastes were carried out: carbide lime (CL), fluoride (FA), sludge-lignin, their material and chemical composition.

As a result of the study, it was demonstrated for the first time that it is possible to obtain mineral cement astringent hydration hardening based on the sludge-lignin of BPPM and slurries of chemical technologies, such as a white fast-hardening cement of high activity.

As a result of the study, it was shown for the first time that it is possible to obtain mineral knitting hydration hardening of the type of white fast-hardening cement of high activity based on sludge-lignin of BPPM and slurries of chemical technologies. 
Thus, the main objective of the study is to justify the possibility, using mineral ferruginous components of raw materials, to synthesize a white mineral binder capable of quickly forming a white artificial stone.

\section{Principle of synthesizing the mineral binder}

To intensify the burning process of Portland cement clinker in order to save thermal energy in the cement industry, various mineralizers are used. The mineralizing effect of various calcium sulfates has been studied. We [3] confirmed that gypsum reduces the firing temperature to $1250-1350^{\circ} \mathrm{C}$, prevents the formation of hydraulically inert gelatite, accelerates the binding of lime. In this case, calcium sulfosaluminates and calcium sulfosilicates are formed in the low-temperature sinter, which are stable in the temperature range $1100-1350^{\circ} \mathrm{C}$. The resulting speck, crushed and water-cured, is able to form a plastic mass (dough), which quickly hardens to form a solid stone.

\section{Basic and auxiliary materials}

The Carbide sludge (CS), which is the slaked, second grade lime with a bluish shade, is the product of the decomposition of calcium carbide in the production of acetylene gas at the Usolye-Siberian chemical plant in the town of Uolie-Sibirskoe.

Fluoride is a waste product of hydrogen fluoride produced at OJSC Angarsk Electrolysis Chemical Combine, Angarsk.

Ash of the sludge lignin. Colloidal sediments with a volume of about $8 \mathrm{~m}^{3}$ are stored in storage maps in the territory of the former Baikal Pulp and Paper Mill (BPPM). The ratio of components in the sediment is the following: lignin substances (40-45\%), fiber (15-20\%), activated sludge (15-20\%), and ash residue (10-20\%). Since alumina and polymethyl acrylate were used as a coagulant and a flocculant for physicochemical treatment of waste water at the BPPM, their residual concentrations are also present in the lignin slurry. In 50 grams of sediment, alumina is contained up to $5 \mathrm{~g}$. When the sludge mass is burned, an ash containing up to $75 \% \mathrm{Al}_{2} \mathrm{O}_{3}$ is formed from the accumulator, which can be the main component for the production of calcium sulphoaluminate, a mineral of white clinker.

Table 1. Chemical composition of components for the preparation of cement charge.

\begin{tabular}{|l|l|l|l|l|l|l|l|l|l|}
\hline Content, \% & $\mathrm{SiO}_{2}$ & $\mathrm{Al}_{2} \mathrm{O}_{3}$ & $\mathrm{Fe}_{2} \mathrm{O}_{3}$ & $\mathrm{CaO}$ & $\mathrm{MgO}$ & $\mathrm{R}_{2} \mathrm{O}$ & $\mathrm{TiO}_{2}$ & $\mathrm{SO}_{3}$ & П.П.П \\
\hline $\begin{array}{l}\text { Carbide } \\
\text { sludge }\end{array}$ & 1,83 & 0,72 & 0,41 & 69,5 & 0,74 & 0.6 & 0,76 & 0,21 & 26,42 \\
\hline Fluoramps & 1,97 & 0,61 & 0,42 & 31,6 & 0,75 & 0,07 & - & 42,6 & 21,7 \\
\hline $\begin{array}{l}\text { Sludge lignin, } \\
\text { ash }\end{array}$ & 22 & 72 & 3 & 2 & - & - & - & 1,0 & \\
\hline
\end{tabular}

\section{Research methodology.}

\subsection{Equipment and tools.}

1) Drying cabinet with a maximum temperature of $250^{\circ} \mathrm{C}$.

2) To measure the mass of samples, electronic scales with a weighing accuracy of $0.01 \mathrm{~g}$.

3) Silite muffle furnace for sintering of raw batch.

4) A mixture of charge components was produced in a laboratory, planetary mill.

6 ) For the production of samples from the obtained cement, hexane-shaped steel molds having a cell size $2,0 * 2,0,2,0 \mathrm{~cm}$. 
7) The maturing of the hardening samples was carried out both in a chamber having a constant humidity of $100 \%$ and a temperature of $22^{\circ} \mathrm{C}$ and in a chamber with a hydraulic seal.

8) The strength of the solidified samples was determined by means of hydraulic presses of the brand Compression Testing Machine of the ИП-6012-1000-1 type.

9) Photometer for measuring the reflection coefficient of an optical surface.

Whiteness of the white Portland cement is determined by the reflection coefficient in percent of the absolute scale.

\subsection{Description of the conditions and procedure for performing the experiment.}

3.2.1. The reflection coefficient is determined by means of a photometer (or similar devices), which is equipped with a photoelectric recording of the indicators and providing an allowable limit of the relative error of determination of not more than $1.5 \%$.

3.2.2. As a standard for determining the reflection coefficient, a matt frosted glass of the MC-20 type with a reflection coefficient of not less than $95 \%$ is used, for which there must be a certificate issued in accordance with the established procedure.

3.2.3. To determine the reflection coefficient, a sample weighing not less than $0.1 \mathrm{~kg}$ being taken from a common sample is used. The sample is dried at the temperature of $105 \pm 5^{\circ} \mathrm{C}$ for at least 1 hour. The dried cement is poured into the cuvette of the device so that the surface of the sample is somewhat convex. Then the sample is compacted by lightly shaking the cuvette, its surface is leveled flush with the top edge of the cuvette, manually pressing a glass plate with a smooth surface. The surface of the sample should be smooth and not have cracks and depressions.

3.2.4. The reflection coefficient is determined in parallel on three cement samples. The arithmetic mean of the three determinations, expressed as a percentage, is taken as the result of the determination, with an accuracy of $1 \%$.

3.2.5. The whiteness is determined according to the instructions attached to the photometer, without applying light filters.

\section{Results}

The cement being derived from low-iron raw materials has a light color. The average result of the whiteness ratio is $72 \%$. This allows us to declare the receipt of white cement based waste industry in the Irkutsk region.

The grinding and mixing of the charge material and the clinker was carried out with the help of a planetary mill, which involves the ingress of iron $\mathrm{Fe} 2 \mathrm{O} 3$ into the feed mixture, and hence it is possible to obtain the lightest cement by avoiding the ingress of iron into the clinker and the charge material.

Table 2. Average results from tested samples.

\begin{tabular}{|c|c|c|c|}
\hline \multirow{2}{*}{ Sample No. } & \multicolumn{2}{|c|}{$\begin{array}{c}\text { Compressive strength, MPa, } \\
\text { depending on the time per day }\end{array}$} & \multirow{2}{*}{$\begin{array}{c}\text { Reflection } \\
\text { coefficient, \% }\end{array}$} \\
\cline { 2 - 3 } & 1 day & 3 day & \\
\hline 1 & 44,1 & & 73 \\
\hline 2 & 42,6 & & 72 \\
\hline 3 & 41,7 & & 71 \\
\hline 4 & & 52,7 & 72 \\
\hline 5 & & 51,9 & 71 \\
\hline 6 & & 53,1 & 73 \\
\hline
\end{tabular}




\begin{tabular}{|c|c|c|c|}
\hline $\begin{array}{c}\text { Average } \\
\text { results from } \\
\text { tested samples }\end{array}$ & 42,8 & 52,6 & 72 \\
\hline
\end{tabular}

\section{Discussion}

The main problem is to obtain the maximum possible whiteness of the cement produced. To solve the problem of white cement contamination from metallic iron additives when grinding clinker or charge materials, it is necessary to use mills with a specially hard-wearing lining.

In our opinion, it is recommended to use grinding bodies that have least of all contaminated with their particles the color of cement, now widely used for this is an artificial material called "uralit."

\section{Conclusion}

The research carried out shows that the cement received from low-iron raw materials has light color. The coefficient of whiteness is $72 \%$. Therefore, such a powder can be used as a decorative binder. The decorative concrete made with the use of cement obtained as a binder has a high mark for strength, durability, and corrosion resistance.

Thus, the material obtained on the basis of mineral residues of sludge-lignin and other man-caused waste has a wide scope of application. In addition, a significant reduction in energy costs (lower fuel consumption, electricity costs in the preparation of raw materials and grinding) makes such cement economically attractive for the construction industry.

\section{References}

1. GOST 965 white Portland cement: technical specifications (Moscow, 1990)

2. A. N. Garachian, White Portland cement technology (Stroyizdat, Moscow, 1970)

3. V. A. Vorobchuk, E. A., Levchenko, A. V. Peshkov, Proceedings of Irkutsk State Technical University, 6(89), 123-125, (2014)

4. A. N. Garachian, V. I. Turchaninov, Cement, 4, 10-11 (1978)

5. E. A. Levchenko, A. V. Bogdanov, Raw material mixture for obtaining hydraulic cement (Patent No. 2552288, 2014)

6. S. S. Cherepovskiy, O. K. Aleshin, Production of white and colored Portland cement (Publishing House of Construction Literature, Moscow, 1964)

7. A. N. Garachian, P. P. Gaidzhurov, A. P. Zubehii, N. V. Rotich, Technology of white Portland cement (Moscow Publishing House, Moscow, 1970)

8. P. I. Bozhenov, L. I. Kholopova, Cement, 4, 15-17 (1960)

9. D. V. Dayneko, A. I. Dayneko, V. V. Peshkov, N. Ya. Kalyuzhnova, Proceedings of Universities. Investment. Construction. Real Estate. 7, 3 (22), 116-120 (2017)

10. V. A. Vorobchuk, A. V. Peshkov, M. V. Matveeva, Certificate of state registration of the database No. 2014621376 "Automation of the complex of tasks to provide construction objects with material resources" (Federal Service for Intellectual Property, 2014) 